\title{
CULTIVATION OF CHINESE SILVERGRASS (MISCANTHUS SINENSIS ANDERSS.) ON THE EAST SLOVAK LOWLAND AS A POTENTIAL SOURCE OF RAW MATERIAL FOR ENERGY PURPOSES
}

\author{
PAVOL PORVAZ ${ }^{1}$, ŠTEFAN TÓTH ${ }^{1}$, ANDREJ MARCIN ${ }^{2}$ \\ ${ }^{1}$ Plant Production Research Center Pieštany \\ ${ }^{2}$ University of Veterinary Medicine and Pharmacy in Košice
}

Porvaz, P. - Tóth, Š. - Marcin, A.: Cultivation of Chinese silvegrass (Miscanthus sinensis Anderss.) on the East Slovak Lowland as a potential source of raw material for energy purposes. Agriculture (Pol'nohospodárstvo), vol. 58, 2012, no. 4, pp. 146-163.

A field trial with Miscanthus sinensis Anderss. was performed in Vysoká nad Uhom (average yearly temperature: $9.0^{\circ} \mathrm{C}$, yearly precipitation: $584 \mathrm{~mm}$ ) on Haplic fluvisol (WRB 2006) during 2006-2009. The average dry matter (DM) yield of the above-ground phytomass was $25.63 \mathrm{t} / \mathrm{ha} /$ year (excluding establish-ment year when yield was $4.81 \mathrm{t} / \mathrm{ha}$ ) and had an increasing trend according to production years $(14.13,26.14$ and $36.63 \mathrm{t} / \mathrm{ha}$ ). We achieved in developing a trial stand in the third year of production when the field coverage of 10 thousand rhizomes being planted per hectare was over $80 \%$; however, it can be used as a denser spacing for the earlier performance of stand with full production capability, which means plantation of 12-13 thousand plants per hectare. The average lower heating value of the organic sample of phytomass, as received (LHV)

Key words: Miscanthus, dry matter, caloric values, energy yield

The use of energy crops opens plenty of non-traditional possibilities in industrial countries. The Chinese silvergrass (Miscanthus sinensis Anderss). for energy purposes has been tested in field trials in many European countries (Wiesler et al. 1997; Price et al. 2004; Danalatos et al. 2007; Gauder et al. 2012). The Chinese silvergrass and fast-growing willow are the first energy crops being cultivated in Slovakia nowadays (Porvaz et al. 2008). There are still many economical and environmental tests needed to be performed in the future. Further research is still needed to optimise agronomy of miscanthus, to develop the production chain and pre-treatment, as well as to optimise energy conservation route to produce heat, electricity and/or was $15.56 \mathrm{MJ} / \mathrm{kg}$, and according to the trial years were 15.09 ; $15.80 ; 15.70$; and $15.80 \mathrm{MJ} / \mathrm{kg}$. The amount of total energy value of the produced phytomass per unit area (energy yield) was $1,284.989 \mathrm{GJ} / \mathrm{ha}$, and $72.583,223.254,410.398,578.754$ $\mathrm{GJ} / \mathrm{ha}$, respectively, in the trial years. The energy yield was exclusively affected $(r=0.999)$, and the caloric value (LHV) was affected by phytomass yield $(r=0.739)$. Obtained emission characteristics and the concentration of selected volatiles, and remaining ash, ash content $3.46 \%$, total water $10.65 \%$, carbon $42.49 \%$, hydrogen $5.20 \%$, total sulphur $0.12 \%$, nitrogen $0.55 \%$, silicone $1.17 \%$ and chlorine $0.16 \%$ have supported the environmentally friendly introduction of Chinese silvergrass, as the energy crop is desirable for the targeted agroecological conditions of Slovakia.

fuels from biomass, and whether miscanthus can compete with the fossil fuel use and be widely produce (Babović et al. 2012).

Gauder et al. (2012) has presented data on the Chinese silvergrass dry matter production under environmental conditions of South Germany. The data indicate a shorter establishment period of Miscanthus $\times$ giganteus and Miscanthus sacchariflorus than of Miscanthus sinensis hybrids and Miscanthus sinensis genotypes. The best yielding genotype was $M . \times$ giganteus with an average dry matter (DM) spring yield of $14.1 \mathrm{t} / \mathrm{ha}$ being presented which could be used for forecasting late winter yields using morphological traits in autumn. At the preliminary tests being performed during

Ing. Pavol Porvaz, PhD., Ing. Štefan Tóth, PhD., Plant Production Research Center Piešt’any, Research Intitute of Agroecology Michalovce, 07101 Michalovce, Špitálska 1273, Slovak Republic. Email: porvaz@minet.sk, toth@minet.sk MVDr. Andrej Marcin, CSc., University of Veterinary Medicine and Pharmacy in Košice, 04181 Košice, Komenského 73, Slovak Republik 
2004-2007 an average yield of 36.54 t/ha/year of Miscanthus sinensis dry matter under conditions of East Slovak Lowland was achieved, whereas the same annual yield of $42.88 \mathrm{t} / \mathrm{ha} /$ year was registered using the highest level of nutrition (Porvaz et al. 2008).

The aim of this research was the determination of selected production parameters, energy values and emission characteristics of the Chinese silvergrass as an energy crop.

\section{MATERIAL AND METHODS}

This research was performed in a field trial on an experimental base in Vysoká nad Uhom (long-term average year temperature: $9.0^{\circ} \mathrm{C}$, long-term year precipitation: $584 \mathrm{~mm}$ ), $20 \mathrm{~km}$ south of Michalovce, with an altitude of $105 \mathrm{~m}$ on Haplic fluvisol without irrigation during 2006-2009. The current meteorological data of the experimental place are shown in Table 1. The Chinese silvergrass stand was established by planting root rhizomes, at $1 \times 1 \mathrm{~m}$ spacing, into finely prepared soil in April 2006. The rhizomes were taken from the parent stand prior to planting. The rhizomes were ploughed out. Subsequently, a lump of soil that weighted approx 1-2 $\mathrm{kg}$ was sliced so that rhizomes with a minimum length of $15 \mathrm{~cm}$ were achieved. The rhizomes were not separated from the soil. All planted rhizomes were viable and had started growing immediately. No fungal diseases or pests were recorded during the growing season. In the year of establishment as well as in the first production year, the stand had low competition with weeds; the weeds were controlled mechanically. In subsequent production years, however, weeds were significantly suppressed by a stand.

The main nutrients, i.e. $\mathrm{N}, \mathrm{P}$ and $\mathrm{K}$, were applied at 60,26 and $50 \mathrm{~kg} / \mathrm{ha}$, respectively, in the establishment year. Only nitrogen was applied at a dose of $40 \mathrm{~kg} / \mathrm{ha}$ in production years. This trial was conducted as a part of more comprehensive polyfactorial field trial being established as a randomized block design with four replications.

Because of the parameterization of production, and the caloric as well as emission characteristics of the Chinese silvergrass, we observed the yield of the above-ground phytomass and selected growth parameters. The biometric measurements were performed on a sample of five plants with four replications. Plant height $[\mathrm{m}]$, number of plant shoots [piece], diameter of stooling circle $[\mathrm{m}]$ as well as dry matter yield of the above-ground phytomass [t/ha] were measured. Consequently, we determined caloric characteristics ( $\mathrm{Q}$ - calorimetrically), higher heating value (HHV) of dry matter, lower heating value (LHV) of organic sample as received, the heat value of the organic sample dried at $105^{\circ} \mathrm{C}$ as well as other important parameters of the above-ground phytomass chemical content where the total water content belongs, ash and total

$\mathrm{T}$ a b 1 e 1

Vysoká nad Uhom - selected climatic characteristics and meteorological data of the experimental site

\begin{tabular}{|l|c|c|c|c|c|}
\hline Month & LTA & 2006 & 2007 & 2008 & 2009 \\
\hline \multicolumn{7}{|c|}{ Precipitation [mm] } \\
\hline I. - XII. & 584 & 576 & 605 & 675 & 712 \\
IV. - IX. & 344 & 366 & 328 & 492 & 246 \\
Character of vegetation period & \multicolumn{7}{|c|}{ Normal } & Normal & Extremely wet & Very arid \\
\hline \multicolumn{7}{|c|}{ Temperature $\left[{ }^{\circ} \mathrm{C}\right]$} \\
\hline X I. - XII. & 9.0 & 9.8 & 11.1 & 10.5 & 10.5 \\
x IV. - IX. & 16.1 & 17.2 & 17.9 & 16.8 & 18.0 \\
Character of vegetation period & \multicolumn{7}{|l|}{ Normal } & Warm & Normal & Warm \\
\hline
\end{tabular}

Source: Slovak Hydrometeorological Institute in Bratislava *LTA - long-term average (1951-1980) 
sulphur in dry matter (w, a, S - gravimetrically), content of carbon, hydrogen and nitrogen $(\mathrm{C}, \mathrm{H}, \mathrm{N}$ - elementary analysis with a heat conducting detector), and the content of silicon ( $\mathrm{Si}$ - atomic emission spectrometry with inductively coupled plasma). The caloric and emission characteristics were determined annually for the average sample.

The obtained data were mathematically processed and are presented as averaged ones. For statistic evaluation we used the correlation, analysis of variance and a multiple range test.

\section{Soil characteristics of the experimental place}

Fluvisol is a sandy-loamy to a loamy soil, welldrained throughout the whole profile. Fluvisols are the medium-heavy soils, based on the content of clay particles, and occupy approximately $26 \%$ of the total area of the East Slovak Lowland.

According to the soil analysis of 2005 , the following values were found: $\mathrm{C}_{\text {ox }}$ content $20.73 \mathrm{~g} / \mathrm{kg}, \mathrm{pH} / \mathrm{KCl}$ 7.14 , bulk density $1532 \mathrm{~kg} / \mathrm{m}^{3}$, total porosity $41.85 \%$, $\mathrm{CaCO}_{3}$ content $2,800 \mathrm{mg} / \mathrm{kg}$, CEC $24.9 \mathrm{mg} / 100 \mathrm{~g}$, base saturation $96.72 \%$, and nutrient content available: $\mathrm{N}_{\text {in }}$ $13.00 \mathrm{mg} / \mathrm{kg}, \mathrm{P} 47.7 \mathrm{mg} / \mathrm{kg}, \mathrm{K} 153 \mathrm{mg} / \mathrm{kg}$ and $\mathrm{Mg}$ $122 \mathrm{mg} / \mathrm{kg}$.

\section{Weather characteristics of the experimental place}

General weather conditions of the experimental base in Vysoká nad Uhom can be characterized as follows: mean annual air temperature during the growing season is $16.3^{\circ} \mathrm{C}$; mean annual sum of precipitation during the growing season is $344 \mathrm{~mm}$; mean total temperature sum of a growing season, a.k.a. thermal vegetation constant, is $2,880^{\circ} \mathrm{C}$; mean annual sunshine duration is 2,200 hours and during a growing season is 1,442 hours. The amount of rainfall varies significantly from year to year and could reach as much as 40 to $60 \%$ of a long term average. An important phenomenon is the unequal distribution of precipitation during the growing season.

During this research period, the following weather data were monitored: an average daily air temperature and the sum of precipitation, obtained by the Slovak Hydrometeorological Institute, where the quality of monitoring is guaranteed. More comprehensive soil and weather characteristics of this experimental location are described by Tóth and Porvaz (2008).

\section{RESULTS AND DISCUSSION}

The average dry matter (DM) yield of the aboveground phytomass of the Chinese silvergrass was $25.63 \mathrm{t} / \mathrm{ha}$ /year (excluding the establishment year) and had an increasing trend (from 14.13 to $36.63 \mathrm{t} / \mathrm{ha}$ ) according to the production years (Table 2). The obtained result of the DM yield of $4.81 \mathrm{t} / \mathrm{ha}$ in the establishment year corresponds to the result (Porvaz et al. 2008) of the parent stand from an identical locality with yield of $7.73 \mathrm{t} / \mathrm{ha}$ in the establishment year (2003). The average yield of the parent stand was $36.54 \mathrm{t} / \mathrm{ha} / \mathrm{year}$ (excluding establishment year) and yields from the first to the fourth production year were $37.18,38.51,36.04$ and $34.43 \mathrm{t} / \mathrm{ha}$, respectively. Field trials throughout

$\mathrm{T}$ a b 1 e 2

Average values of the Chinese silvergrass biometric parameters

\begin{tabular}{|c|c|c|c|c|}
\hline Year & $\begin{array}{l}\text { Plant height } \\
{[\mathrm{m}]}\end{array}$ & $\begin{array}{l}\text { Diameter of stooling } \\
\text { circle }[\mathrm{m}]\end{array}$ & $\begin{array}{l}\text { Number of plant } \\
\text { shoots [piece] }\end{array}$ & $\begin{array}{l}\text { Yield of phytomass } \\
{[\mathrm{t} / \mathrm{ha}]}\end{array}$ \\
\hline 2006 & $1.31^{\mathrm{a}}$ & $0.35^{\mathrm{a}}$ & $17.50^{\mathrm{a}}$ & $4.81^{\mathrm{a}}$ \\
\hline 2007 & $2.11^{\mathrm{b}}$ & $0.61^{\mathrm{b}}$ & $33.00^{\mathrm{b}}$ & $14.13^{\mathrm{b}}$ \\
\hline 2008 & $3.06^{\mathrm{c}}$ & $0.73^{c}$ & $57.50^{\mathrm{c}}$ & $26.14^{\mathrm{c}}$ \\
\hline 2009 & $3.15^{\mathrm{d}}$ & $0.83^{\mathrm{d}}$ & $76.75^{\mathrm{d}}$ & $36.63^{\mathrm{d}}$ \\
\hline$\overline{\mathrm{x}}$ & 2.41 & 0.63 & 46.19 & 20.43 \\
\hline $\mathrm{LSD}_{0.05}$ & 0.07 & 0.08 & 6.39 & 6.43 \\
\hline
\end{tabular}

Means with different letters are significantly different at $\alpha=0.05$ and belong to different homogenous groups separated by multiple range test 
different parts of Europe within the last twenty years have confirmed the potential of the Chinese silvergrass for the high biomass production. The above-ground yields of up to 40 tonnes of dry matter/ha/year have been claimed by Van der Werf et al. (1992), which is being advocated as a biomass or fibre crop for northwestern Europe. According to Ercoli et al. (1999) after an establishment period of one year, cultivation of the Chinese silvergrass resulted in a DM production greater than $37 \mathrm{t} / \mathrm{ha} /$ year over a period of four years under conditions of south Europe. Christian et al. (2008) documents the yield, which increased for the first six years decreased in the seventh and the eighth year, but increased again and was the highest in the tenth year averaging $17.7 \mathrm{t} / \mathrm{ha}$ across all treatments of 14-year lasting field experiment in a silty clay loam soil. The paper of Price et al. (2004) reports information for the long-term yield of Chinese silvergrass growing at seven sites in England, where field trials have shown that the potential productivity of Miscanthus $\times$ giganteus is good, with the sites that are situated to Miscanthus $\times$ giganteus cropping capable of DM yields in excess of $20 \mathrm{t} / \mathrm{ha} /$ year. However further comparisons with fastgrowing herbaceous and woody plants are needed and it is obvious that neither fast-growing willow nor perennial herbaceous energy crops cultivation will be realized on the most fertile soils but on less fertile ones; a yield potential of the Chinese silvergrass is higher than the other field crops usually cultivated in Slovakia. In accordance with our earlier findings (Porvaz et al. 2008), assumption of a successful utilization of the Chinese silvergrass for energy purposes was confirmed and there is a supposition of a sustainable cultivation of fully developed stand as a perennial culture both in low input and intensive cropping.

The replications had no statistically significant effect on yield variability (Table 3 ) which confirmed the experiment's reliability. The mean squares of the replication were approximately the same or a little higher in comparison with the mean squares of the residual which includes an experimental error. It can be caused by the stand establishment method. The stand was established by planting rhizomes with reliable but different viability.

The different viability of the individual plants was expressed by the different values of the observed biometric parameters of the young, still developing, stand (Table 2) which were in a strong correlation with the yield of the Chinese silvergrass. The yield of phytomass correlated strongly with the diameter of stooling circle $(r=0.942)$. In terms of plant height $(r=0.920)$ and the number of plant shoots $(r=0.813)$, the observed relation had a similar character. The plant height achieved $1.31 \mathrm{~m}$ in the year of the stand establishment and increased up to $3.06 \mathrm{~m}$ in the second production year, and $3.15 \mathrm{~m}$ in the third year. The number of plant shoots achieved 17.50 pieces in the year of the stand establishment and increased up to 76.75 in the third production year, what strongly correlated $(r=0.954)$ with an increasing of a stooling circle diameter which directly expresses a stand coverage of the field. According to Pósa and Percze (2011), the requirement of a successful production of the Chinese silvergrass is a well timed establishment of the plantation and coverage of a field above $90 \%$ by the $2^{\text {nd }}$ and $3^{\text {rd }}$ year. By planting rhizomes we achieved in developing a stand

$\mathrm{T}$ a b 1 e 3

Mean square data of analysis of variance of the Chinese silvergrass biometric parameters

\begin{tabular}{|l|c|c|c|c|c|}
\hline $\begin{array}{l}\text { Source of } \\
\text { variability }\end{array}$ & df & Plant height & $\begin{array}{c}\text { Diameter of stooling } \\
\text { circle }\end{array}$ & Number of plant shoots & Yield of phytomass \\
\hline Year & 3 & $3.027^{++}$ & $0.1697^{++}$ & $2745.2^{++}$ \\
Replication & 3 & $0.004^{-}$ & $0.0183^{++}$ & $100.4^{++}$ \\
Residual & 9 & 0.001 & 0.0024 & -15.9 \\
Total & 15 & - & - & - \\
\hline
\end{tabular}

df - degree of freedom

${ }^{++}$- the factor has a significant effect on the observed parameter at the $95.0 \%$ confidence level

- non-significant effect 
of trial which covered $80 \%$ of the field in the third year of production. Although it can be used as a denser spacing for earlier performance of a full production capability stand, i.e. plantation of 12-13 thousand plants per hectare. The other requirements for successful production are a rational cultivation, weed control, and primarily the selection of a proper propagation material. Both the seedlings and the rhizomes can be used for the multiplication of the Chinese silvergrass, although we favour the latter for better results under conditions of central Europe. The main problem can be the low rate of survival during the first winter after the stand establishment when the seedlings are being planted. However a stand with optimal development can be obtained; there is no assumption to achieve the differences in total production over the years within $5 \%$ between the highest and lowest yielding documented by Christian et al. (2008) from west Europe under very variable weather conditions of East Slovak Lowland (Table 1). There was $492 \mathrm{~mm}$ (143\% of longterm average) of precipitations on an experimental site during a vegetation period in 2008 and subsequently in 2009 the same characteristic was only $246 \mathrm{~mm}$ (72\% of long-term average). In Heaton's et al. (2004) examination of all peer-reviewed articles describing productivity of Chinese silvergrass, despite being on the different continents (Europe and North America), the crop showed a significant positive response to water, but not to a temperature.

Experiments with the Chinese silvergrass at the field conditions with different genotypes are also presented in the works of Clifton-Brown and Lewandowski (2002). Harvest period factors, lodging, trimming, fertilization, mechanical and morphological properties of the plants (Kaack \& Schwarz 2001) were observed as well. A minimum of two years of cultivation is necessary to achieve a high biomass yield with good quality for new genotypes of the Chinese silvergrass tested in Germany (Clifton-Brown \& Lewandowski 2002). This observation was found by measuring 15 genotypes in Southern Germany for three years of cultivation. Some studies have compared the success in sowing the coated and uncoated seeds of the Chinese silvergrass (Christian et al. 2005).

The nitrogenous nutrition of the Chinese silvergrass has a statistically significant positive influence on the first year of growing by Wiesler et al. (1997) on a plant growth particularly in the first seven weeks. For the second year of cultivation the author mentioned the regrowth of the plants in spring affected by the previous supply of N, whereas during five weeks the regrowth of the above-ground dry matter significantly correlated with $\mathrm{N}$ content in the rhizomes. The highest $\mathrm{N}$ uptake was found by them in the first year of cultivation and

$\mathrm{T}$ a b 1 e 4

The caloric and emission analysis of Chinese silvergrass (2006-2009)

\begin{tabular}{|c|c|c|c|c|c|}
\hline Indicator & 2006 & 2007 & 2008 & 2009 & $\overline{\mathrm{x}}$ \\
\hline Higher heating value $[\mathrm{MJ} / \mathrm{kg}]$ & 19.19 & 18.76 & 19.20 & 19.10 & 19.02 \\
\hline Heat value of organic sample dried at $105^{\circ} \mathrm{C}[\mathrm{MJ} / \mathrm{kg}]$ & 17.92 & 17.54 & 17.90 & 17.70 & 17.72 \\
\hline Lower heating value of organic sample as received $[\mathrm{MJ} / \mathrm{kg}]$ & 15.09 & 15.80 & 15.70 & 15.80 & 15.56 \\
\hline Total water $[\%]$ & 13.88 & 8.71 & 9.56 & 9.35 & 10.65 \\
\hline Analytical water $[\%]$ & 5.31 & 3.88 & 4.90 & 4.82 & 4.67 \\
\hline Ash [\%] & 5.20 & 3.16 & 2.01 & 2.01 & 3.46 \\
\hline Total sulphur [\%] & 0.06 & 0.16 & 0.13 & 0.13 & 0.12 \\
\hline Hydrogen [\%] & 5.01 & 5.10 & 5.50 & 5.50 & 5.20 \\
\hline Carbon [\%] & 41.27 & 43.41 & 42.90 & 42.80 & 42.49 \\
\hline Nitrogen [\%] & 1.12 & 0.36 & 0.18 & 0.18 & 0.55 \\
\hline Silicon [\%] & 1.79 & 1.09 & 0.65 & 0.63 & 1.17 \\
\hline Chlorine [\%] & - & 0.16 & - & - & 0.16 \\
\hline
\end{tabular}


$\mathrm{N}$ had a major part in the growth of rhizomes and the whole root system. Similar conclusions were found by Danalatos et al. (2007) by testing Miscanthus $\times$ giganteus for the biomass production under the conditions of Central Greece. These are the results of a two-year experiment involving two levels of nitrogen 50 or 100 $\mathrm{kg} \mathrm{N} / \mathrm{ha}$ and different stand densities $0.66,1$ and 2 plants $/ \mathrm{m}^{2}$ with the highest yield of biomass $(38 \mathrm{t} / \mathrm{ha}$ ) in the experiment. In spite of the mentioned studies of cropping intensification, by Christian et al. (2008) the crop can be also considered as a low input crop with a high level of sustainability.

The combustion of phytomass of the Chinese silvergrass meets qualitative as well as ecological criteria for a content of atmospheric emissions (Lewandowski \& Kicherer 1997). The main characteristics are heating values, water content, concentration of chlorine and ash, and concentration of volatiles and remaining ash. Further quality criteria are the concentrations of nitrogen, sulphur, potassium, and calcium. The obtained data regarding the selected caloric and emission characteristics are presented in Table 4.
The average higher heating value (HHV) was $19.02 \mathrm{MJ} / \mathrm{kg}: 19.19,18.76,19.20$ and $19.10 \mathrm{MJ} / \mathrm{kg}$, respectively, in the trial years. The average lower heating value of an organic sample of phytomass as received (LHV) was $15.56 \mathrm{MJ} / \mathrm{kg}$. The total energy value of the produced phytomass per unit area (energy yield) was $72.583,223.254,410.398,578.754 \mathrm{GJ} / \mathrm{ha}$, respectively, in the trial years (Figure 1). The average heat value of organic sample dried at $105^{\circ} \mathrm{C}$ was $17.72 \mathrm{MJ} / \mathrm{kg}$. According to the results, the energy yield was exclusively affected $(r=0.999)$ and a caloric value of the Chinese silvergrass was affected by the phytomass yield (LHV, $r=0.739$ ). According to Ercoli et al. (1999) the caloric value of the crop $(16.5 \mathrm{MJ} / \mathrm{kg})$ is not affected by irrigation and fertilization, instead the energy production depends exclusively on the biomass yield, which is in agreement with our finding. Without $\mathrm{N}$ supply and irrigation they achieved an energy yield of $291 \mathrm{GJ} / \mathrm{ha} / \mathrm{year}$ of which the maximum was $564 \mathrm{GJ} / \mathrm{ha} / \mathrm{year}$ after treatment. The irrigation and the nutrition level (mean current agronomic measures) can greatly affect the crop yield and the total energy yield on East Slovak Lowland as well.

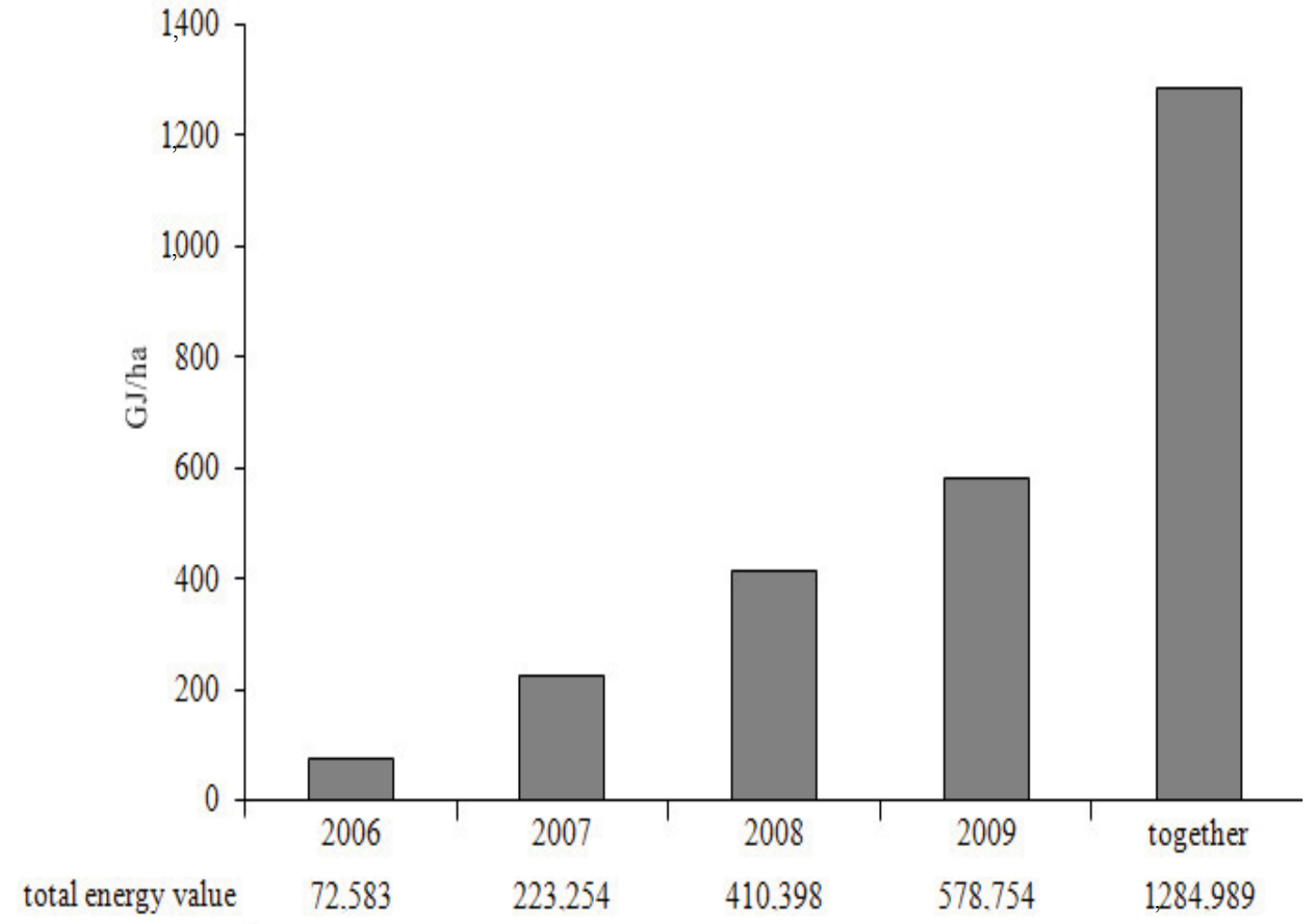

Figure 1. The total energy value of above-ground phytomass per hectare (2006-2009) 
According to Lewandowski and Kircherer (1997) the concentrations of water, minerals and ash, all three of which should be as low as possible, were higher in a biomass from cold and humid location than in a biomass from a warm location. As discussed above, the application of potassium fertilizer leads to increase in ash and potassium concentrations. The harvesting of the Chinese silvergrass in February instead of December led to improved quality because the concentrations of ash, minerals and especially of water had declined. Compared to other lignocellulose plants the Chinese silvergrass phytomass has a very good combustion quality. In February the stems of the crop had a water concentration of only $16-33 \%$. The mineral concentrations were also low with $0.2-0.3 \mathrm{~g} / \mathrm{kg}$ for chlorine, $0.9-3.4 \mathrm{~g} / \mathrm{kg}$ for nitrogen and 3.7-11.2 $\mathrm{g} / \mathrm{kg}$ for potassium. According to Sander (1997) the high content of potassium and chlorine in solid biofuels causes a number of serious technical problems. The major conclusions of his investigations are that no correlation is seen between the content of potassium and chlorine in phytomass and the soil type, nitrogen and potassium fertilizer dose, pesticide dose and geographic location; that there is a strong correlation between the chlorine content in phytomass and supply of chlorine with fertilizer; that the content of potassium and chlorine is dependent on the variety. Our results on emission elemental compositions and the concentration of selected volatiles and remaining ash, such as total water (10.65\%), carbon $(42.49 \%)$, ash content $(3.46 \%)$, total sulphur $(0.12 \%)$, hydrogen $(5.20 \%)$, nitrogen $(0.55 \%)$, silicone $(1.17 \%)$ and chlorine $(0.16 \%)$ (Table 4$)$, are supporting environmentally the friendly introduction of the Chinese silvergrass as an energy crop which is desirable for the agroecological conditions of Slovakia. To draw more comprehensive agro-environmental conclusions there is a need for further analyses.

\section{CONCLUSION}

The Chinese silvergrass (Miscanthus sinensis Anderss.), is perennial tall grass with $\mathrm{C}_{4}$ type photosynthesis. This plant effectively utilizes the solar energy, water and nutrients for the dry matter production. The yield potential is over $30 \mathrm{t} / \mathrm{ha}$ of total dry matter under favourable conditions as are stated in many scientific sources. We tested its production potential in the defined conditions of nutrition, energy value of caloric characteristics indicators of the plant suitable for burning in the conditions of the East Slovak Lowland. The achieved average production of a dry matter of the biomass was in the field experiments $36.54 \mathrm{t} / \mathrm{ha}$ on Haplic fluvisol in the years 2004-2007. This type of a soil belongs to the most fertile soils in the East Slovak Lowland. It is obvious that neither fast-growing willow nor perennial herbaceous energy crops cultivation will be applied on the most fertile soils but on less fertile ones; therefore we expect that our yield results to be of the highest level which may be achieved under conditions of the whole of Slovakia. The caloric and emission characteristics of the Chinese silvergrass were favourable. The average higher heating value of the above-ground phytomass was $19.02 \mathrm{MJ} / \mathrm{kg}$. The adequate values were 19.19, 18.76, 19.20 and $19.10 \mathrm{MJ} / \mathrm{kg}$, respectively, in the trial years. The total energy value of the produced phytomass per unit area was $72.583,223.254,410.398$ and $578.754 \mathrm{GJ} / \mathrm{ha}$, respectively, in the trial years. It is assumed that the Chinese silvergrass (Miscanthus sinensis Anderss.), can thus be successfully utilized as an energy crop.

Acknowledgment: This work was supported by the Slovak Ministry of Agriculture through the research project CS 2006 27/091 05 01/091 05 10-03-04 “Solution of competition and ecologization of crop production in Slovak regions by means of management systems on agricultural land and innovation of cropping systems".

\section{REFERENCES}

BABOVIĆ, N.V. - DRAŽIĆ, G.D. - DORDEVIĆ, A.M. 2012. Potential uses of biomass from fast-growing crop Miscanthus $\times$ gigantheus (Review) [Mogućnosti korišćenjabiomase poreklom od brzorastuće trske Miscanthus $\times$ gigantheus]. In Hemijska Industrija, vol. 66, 2012, no. 2, pp. 223-233.

CHRISTIAN, D.G. - YATES, N.E. - RICHE, A.B. 2005. Establishing Miscanthus sinensis from seed using conventional sowing methods. In Industrial Crops and Products, vol. 21, 2005, no. 1, pp. 109-111. DOI:10.1016/ j.indcrop.2004.01.004

CHRISTIAN, D.G. - RICHE, A.B. - YATES, N.E. 2008. Growth, yield and mineral content of Miscanthus $\times g i$ gantheus grown as a biofuel for 14 succesive harvest. In Industrial Crops and Products, vol. 28, 2008, no. 3, pp. 320-327. DOI:10.1016/j.indcrop.2004.01.004

CLIFTON-BROWN, J.C. - LEWANDOWSKI, I. 2002. Screening miscanthus genotypes in field trials to optimise bio- 
mass yield and quality in Southern Germany. In European Journal of Agronomy, vol. 16, 2002, no. 2, pp. 97-110.

DANALATOS, N.G. - ARCHONTOULIS, S.V. - MITSIOS, I. 2007. Potential growth and biomass productivity of Miscanthus $\times$ gigantheus as affected by plant density and $\mathrm{N}$-fertilization in central Greece. In Biomass and Bioenergy, vol. 31, 2007, no. 2-3, pp. 145-152. DOI: 10.1016/ j.biombioe.2006.07.004

ERCOLI, L. - MARIOTTI, M. - MASONI, A. - BONARI, E. 1999. Effect of irrigation and nitrogen fertilization on biomass yield and efficiency of energy use in crop production of Miscanthus. In Field Crops Research, vol. 63, 1999, no. 1, pp. 3-11.

GAUDER, M.- GRAEFF-HÖNNINGER, S. - LEWANDOWSKI, I. - CLAUPEIN, W. 2012. Long-term yield and performance of 15 different Miscanthus genotypes in southwest Germany. In Annals of Applied Biology, vol. 160, 2012, no. 2, pp. 126-136. DOI: 10.1111/j.1744-7348.2011.00526.x

HEATON, E. - VOIGT, T. - LONG, S.P. 2004. A quantitative review the yields of two candidate $\mathrm{C} 4$ perennial biomass crops in relation to nitrogen, temperature and water (Review). In Biomass and Bioenergy, vol. 27, 2004, no. 1, pp. 21-30 DOI:10.1016/j.biombioe.2003.10.005

KAACK, K. - SCHWARZ, K-U. 2001. Morphological and mechanical properties of Miscanthus in relation to harvesting, lodging, and growth conditions. In Industrial Crops and Products, vol. 14, 2001, no. 2, pp. 145-154.

IUSS Working Group WRB. 2006. World Reference Base for soil Resources 2006. World Soil Resources Report No. 103. Rome : FAO, 2006, pp. 145. ISBN 9. 2-5-105511-4

LEWANDOWSKI, I. - KICHERER, A. 1997. Combustion quality of biomass: Practical relevance and experiments to modify the biomass quality of Miscanthus $\times$ giganteus. In European Journal of Agronomy, vol 6, 1997, no. 3-4, pp. $163-177$.

PORVAZ, P. - MATI, R. - KOTOROVÁ, D. - JAKUBOVÁ, J. 2008. Pestovanie ozdobnice čínskej (Miscanthus sinensis Anderss.) [Growing of Miscanthus sinensis Anderss] In Methodological Guide. Published by SARC-TA Michalovce, 32 pp. ISBN 978-80-88872-93-1

PÓSA, B. - PERCZA, A. 2011. A kínai nád (Miscanthus sinensis) magyarországi termesztéseének megalapozása
[Establishing the Hungarian production of Chinese silver grass (Miscanthus sinensis)]. In Novenytermeles, vol. 60, 2011, no. 4, pp. 95-114.

PRICE, L. - BULLARD, M. - LYONS, H. - ANTHONY, S. - NIXON, P. 2004. Identifying the yield potential of Miscanthus $\times$ gigantheus: An assessment of the spatial and temporal variability of Miscanthus $\times$ gigantheus biomass productivity across England and Wales. In Biomass and Bioenergy, vol. 26, 2004, no. 2, pp. 3-13. DOI:10.1016/ S0961-9534(03)00062-X

SANDER, B. 1997. Properties of Danish biofuels and the requirements for power production. In Biomass and Bioenergy, vol. 12, 1997, no. 3, pp. 177-183.

TÓTH, Š. - PORVAZ, P. 2008 Vplyv aplikácie vybraných bakteriálnych preparátov na celkový počet mikroorganizmov v pôde, vrátane efektu opakovanej aplikácie versus spontánnej adaptácie, pri použití herbicídov acetochlor a sulfosulfuron [The influence of selected bacterial preparations on colony forming units of microorganisms in soil, including effect of repeated application versus spontaneous adaptation, at acetochlor or sulfosulfuron herbicide using]. In Agriculture (Polnohospodárstvo), vol. 54, 2008, no. 4, pp. $145-154$.

Van der WERF, H.M.G. - MEIJER, W.J.M. - MATHIJSSEN, E.W.J.M. - DARWINKEL, A. 1992. Potential dry matter production of Miscanthus sinensis in The Netherlands. In Industrial Crops and Products, vol. 1, 1992, no. 2-4, pp. 203-210.

WIESLER, F. - DICKMANN, J. - HORST, W. J. 1997. Effects of nitrogen supply on growth and nitrogen uptake by Miscanthus sinensis during establishment. In Journal of Plant Nutrition and Soil Science, vol. 160, 1997, no. 1, pp. 25-31. DOI: $10.1002 /$ jpln.19971600107

Received: September $7^{\text {th }}, 2010$ 